\title{
PROMOTING ENGLISH LEARNERS' PRONUNCIATION OF INFLECTIONAL SUFFIXES-S AND -ES THROUGH JAZZ CHANTS
}

\author{
Putri Devi Lestari \\ A Student of Universitas PGRI AdiBuana Surabaya \\ putripdl@yahoo.com \\ Mochamad Ndaru Purwaning Laduni \\ A Student of Universitas PGRI AdiBuana Surabaya \\ ndarupurwaning@gmail.com \\ Wahju Bandjarjani \\ Universitas PGRI AdiBuana Surabaya \\ wahyubanjaryani@yahoo.co.id
}

\begin{abstract}
This paper aims at sharing the writers' experiences in tackling the English learners' problems in pronouncing the inflectional suffixes- $s$ and $-e s$ by means of a type of media, called "Jazz Chants". These are Carolyn Graham's snappy, upbeat chants and poems that use jazz rhythms to illustrate the natural stress and intonation patterns of conversational American English. Based on the observations during pronunciation practice classes towards the performances in pronouncing the inflectional suffixes $-s$ and $-e s$ of the English learners or students in the first semester of the English Language Education Department of the Faculty of Teacher Training and Education in Universitas PGRI Adi Buana Surabaya, it turns out that employing Jazz Chants has made it easier for the learners to be aware of the different ways of pronouncing the inflectional suffixes $-s$ and $-e s(/ \mathrm{s} /, / \mathrm{z} /$, and /Iz or $\partial \mathrm{z} /)$ in different type of the final sound of a word. In other words, the learners' pronunciation of inflectional suffixes $-s$ and $-e s$ is promoted through the implementation of Jazz Chants during pronunciation practices.
\end{abstract}

Keywords: promoting, pronunciation, inflectional suffixes $-s$ and $-e s$, jazz chants

\section{INTRODUCTION}

This study starts from the writers' experiences in pronunciation practice classes in the English Language Education Department of the Faculty of Teacher Training and Education, Universitas PGRI Adi Buana (UNIPA) Surabaya and the judgments of some English lecturers who state that there are still many students who have difficulties in distinguishing between- $s$ and $-e s$ pronunciation during pronunciation exercises and conversation classes. These students' difficulties in pronunciation have been the platform of the writers to provide the simplest and 
most interesting way in practicing the pronunciation of $-s$ and $-e s$ in terms of inflectional suffixes. The fact shows that there are still many new English learners or freshmen and even those of the later semester students who still pronounce either $-s$ or $-e s$ suffix by pronouncing it as simply /s/ in any kind of context, whereas it can be pronounced in three different ways depending on the final sound of a word. In fact, $-s$ and/or $-e s$ in terms of inflectional suffixes is actually pronounced in three ways,namely /s/, /z/, and /Iz or oz/.By using Jazz Chants, students are able to practice the above suffixes and learn about stress, intonation, and rhythm in a natural way. Moreover, regarding the materials of jazz chants which focus on different vocabulary and grammar; teachers can also lead students to review important words with the structure. Therefore, in this paper, the authors are going to discuss the pronunciation of inflectional suffixes $-s$ and $-e s$ through Jazz Chants.

\section{DISCUSSION}

Inflection is the realization of morpho-syntactic features through morphological means (Aronoff and Fudeman, 2011). Suffix is a letter or group of letters added to the end of a word or root (i.e., a base form), serving to form a new word or functioning as an inflectional ending (Richards and Rodgers, 1999). In other words, inflectional suffix can also be defined as a type of affix whichis added to the end of a base wordused for grammatical needs without changing the whole meaning. There are some types of inflectional suffix. Here they are:

Table 1.Types of Inflectional Suffix

\begin{tabular}{|c|c|}
\hline$-S$ & Example \\
\hline $\begin{array}{l}\text { Addition of }-s / \text {-es to noun which forms a } \\
\text { plural noun }\end{array}$ & $\begin{array}{l}\text { Book - books, worker - workers, } \\
\text { pen - pens } \\
\text { A book - two books, one worker - } \\
\text { three workers, one pen - some } \\
\text { pens } \\
\text { watch - watches, box - boxes } \\
\text { A watch - some watches, one box } \\
\text { - many boxes }\end{array}$ \\
\hline $\begin{array}{l}\text { Addition of }-s /-e s \text { to a simple present } \\
\text { tense verb when the subject is } 3^{\text {rd }} \text { person } \\
\text { singular noun }\end{array}$ & $\begin{array}{l}\text { Sing - sings, play - plays, catch - } \\
\text { catches } \\
\text { I sing - She sings. We play - He } \\
\text { plays. The people catch - Shinta } \\
\text { catches. }\end{array}$ \\
\hline -ing & Example \\
\hline $\begin{array}{l}\text { Addition of -ing to verb which is used for } \\
\text { changing the form into continuous tense } \\
\text { and/or adjective }\end{array}$ & $\begin{array}{l}\text { Dance - dancing, type - typing } \\
\text { She dances every Sunday } \\
\text { afternoon. - Now she is dancing. } \\
\text { He types the paper everyday. - At } \\
\text { present he is typing it again. }\end{array}$ \\
\hline
\end{tabular}




\begin{tabular}{|c|c|}
\hline & $\begin{array}{l}\text { The dancing (as adjective) girl is } \\
\text { skilful. }\end{array}$ \\
\hline$-e r$ & Example \\
\hline $\begin{array}{l}\text { Addition of }-e r \text { to adjective or adverb } \\
\text { changing the form into comparative } \\
\text { degree of comparison }\end{array}$ & $\begin{array}{l}\text { Smart - smarter, busy - busier } \\
\text { John is smart, but his brother is } \\
\text { even smarter. } \\
\text { The rector is busy, but the } \\
\text { president is even busier. }\end{array}$ \\
\hline -est & Example \\
\hline $\begin{array}{l}\text { Addition of -est to adjective or adverb } \\
\text { changing the form into superlative degree } \\
\text { of comparison }\end{array}$ & $\begin{array}{l}\text { Great - greatest, big - biggest } \\
\text { The conference is great. It is the } \\
\text { greatest one this year. } \\
\text { Mrs. Hartini's house is big. That is } \\
\text { the biggest house here. }\end{array}$ \\
\hline$-e d,-d,-t$ & Example \\
\hline $\begin{array}{l}\text { Addition of }-e d,-d, \text { and }-t \text { to a base form } \\
\text { of regular verb changing it into simple } \\
\text { past and/or past participle }\end{array}$ & $\begin{array}{l}\text { Learn-learned/learnt, show- } \\
\text { showed } \\
\text { The students learn to pronounce } \\
\text { the difficult sound everyday. They } \\
\text { have learned/learnt it well now. } \\
\text { They show the project to Mr. } \\
\text { Anton regularly. Recently, they } \\
\text { have just showed/shown the } \\
\text { project to Mr. Anton. }\end{array}$ \\
\hline
\end{tabular}

Table 2. The Appearance of Inflectional Suffix $-s$ and/or $-e s$

\begin{tabular}{|l|l|}
\hline Context & Example \\
\hline Regular Plural Noun & One book -- Many books \\
\cline { 2 - 2 } & One watch - Three watches \\
\hline \multirow{2}{*}{$\begin{array}{l}\text { Third Person Singular Verb in Simple } \\
\text { Present Tense }\end{array}$} & I go - She goes \\
\cline { 2 - 2 } & We speak - He speaks \\
\hline Possessive Adjectives & $\begin{array}{l}\text { That is my book - This is Putri's } \\
\text { book, That is Siyas' book. }\end{array}$ \\
\hline Possessive Pronoun & That is my book - This is Ndaru's. \\
\hline
\end{tabular}




\begin{tabular}{|l|l|}
\hline The Abbreviation of 'is' and 'has' & It's (is) my book. \\
\cline { 2 - 2 } & It's (has) been so long. \\
\cline { 2 - 2 } & It's (is) written by Tom. \\
\hline
\end{tabular}

\section{The Pronunciation of $-s$ and/or $-e s$}

Regarding the kind of inflectional suffixes which have been mentioned above, it is found from the study that there are still many English learners who have difficulties in pronouncing the $-s$ and $-e s$ suffixes. Most students think that the pronunciation of $-s$ and $-e s$ suffixes in the English language are pronounced the same way as /s/. In fact, the $-s$ and -es suffixes are actually pronounced in three ways, namely /s/, /z/, and /Iz/or /oz/. It has been a vital problem for the English teachers to teach the English learners about the pronunciation, because wrong pronunciation of the English language, such as stress and intonation can cause a different meaning. It is the thing which we will understand what is important and what to focus on. For example, the word 'record' has different stress between the verb and noun. 'Record' in noun is pronounced as /'rekJ: $\mathrm{d} /$; while in verb form, it is pronounced as $/ \mathrm{rI}^{\prime} \mathrm{ko}: \mathrm{d} /$. Indeed, it works the same way as inflectional suffix-s and/or -es, which in this case is the different pronunciation among /s/, /z/, and / Iz/ or /əz/ in the inflectional suffixes. Besides, jazz chants also provide many advantages such as using natural spoken English,being able to be used in classes of any size,not requiring any special materials, being able to be presented orally or using a tape recorder,able to be used with all age groups, and not requiring musical ability. Based on the reasons, the authors are going to give a solution for the English teachers or lecturers to teach the pronunciation of inflectional suffixes $-s$ and/or - esto English learners by an interesting method called jazz chants. Jazz chant is a fun way to practice stress and rhythm in the classroom. It helps the students sound more natural when they speak. Moreover, it can also boost the students' skill of their vocabularies and grammar patterns.

Here are examplesof the phonetic symbols of words that have $-s$ and/or -es suffixes which determine the pronunciations:

Table 3. The Pronunciations of $-s$ and/or $-e s$

\begin{tabular}{|c|c|c|c|}
\hline Context & $\begin{array}{l}/ \mathrm{s} / \\
\text { After voiceless } \\
\text { consonants } \\
\left(\operatorname{except} / \mathrm{s}, \int, \mathrm{t} f / \text { : }\right. \\
/ \mathrm{p}, \mathrm{k}, \mathrm{t}, \mathrm{f}, \boldsymbol{\theta} /\end{array}$ & 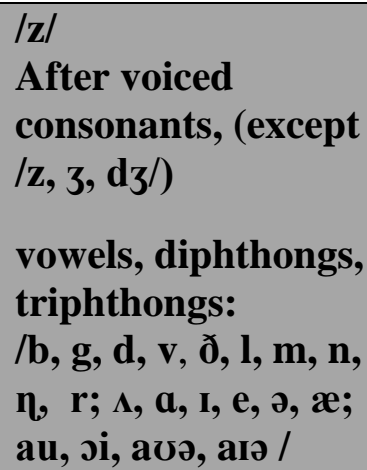 & $\begin{array}{l}\text { /Iz/or /əz/ } \\
\text { After hissing } \\
\text { sounds: } \\
/ \mathrm{s}, \int, \mathbf{t} \int, \mathbf{z}, 3, \mathbf{d}_{3} /\end{array}$ \\
\hline
\end{tabular}


Journal of English Teaching Adi Buana, Vol. 02 No. 01, April 2017

\begin{tabular}{|c|c|c|c|}
\hline $\begin{array}{l}\text { Regular } \\
\text { Plural Noun }\end{array}$ & $\begin{array}{l}\text { weeks /wi:ks/ } \\
\text { fruits /fru:ts/ } \\
\text { units /junits/ } \\
\text { beliefs /bilifs/ }\end{array}$ & $\begin{array}{l}\text { babies /'beibiz/ } \\
\text { lives /laıvz/ /lıvz/ } \\
\text { apples /æplz/ } \\
\text { knives /naIvz/ }\end{array}$ & $\begin{array}{l}\text { boxes /bpksiz/ } \\
\text { or /boksəz/ } \\
\text { garages } \\
\text { /gə' razız/ or } \\
\text { /gə'razəz/ } \\
\text { judges } \\
\text { /'dz^dzIz/ or } \\
\text { /'dz^dzəz/ }\end{array}$ \\
\hline $\begin{array}{l}\text { Third } \\
\text { Person } \\
\text { Singular } \\
\text { Subject }\end{array}$ & $\begin{array}{l}\text { takes /terks/ } \\
\text { writes /raits/ } \\
\text { speaks/spi:ks/ }\end{array}$ & 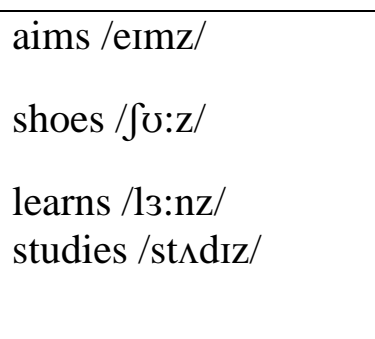 & 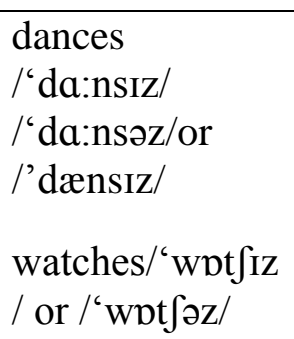 \\
\hline $\begin{array}{l}\text { Possessive } \\
\text { Adjectives }\end{array}$ & $\begin{array}{l}\text { That is Rikat's } \\
\text { pen. } \\
\text { /ðətızrikats pen/ }\end{array}$ & $\begin{array}{l}\text { That is the banker's } \\
\text { house } \\
\text { / } \\
\text { ðætızðəbæykərzhaus } \\
\text { / } \\
\text { That is Putri's book } \\
\text { / ðætızputrızbok/ }\end{array}$ & $\begin{array}{l}\text { That is Siyas's } \\
\text { book } \\
\text { / } \\
\text { ðætızsijasızbøk/ }\end{array}$ \\
\hline $\begin{array}{l}\text { Possessive } \\
\text { Pronoun }\end{array}$ & $\begin{array}{l}\text { The house is } \\
\text { Harahap's } \\
\text { /ðə } \\
\text { 'hausizharahaps } \\
\text { / }\end{array}$ & $\begin{array}{l}\text { The T-Shirt's Lutfi's } \\
= \\
\text { /ðə 'ti: } \int 3 \text { :tslutfi:z/ }\end{array}$ & $\begin{array}{l}\text { The ring is } \\
\text { Dimas's }= \\
\text { / } \\
\text { ðərıjızdimasız/ }\end{array}$ \\
\hline $\begin{array}{l}\text { The } \\
\text { Abbreviatio } \\
\text { n of 'is' and } \\
\text { 'has' }\end{array}$ & $\begin{array}{l}\text { It's (is) my } \\
\text { phone } \\
\text { / Itsmajfoun/ } \\
\text { It's (is) very } \\
\text { difficult } \\
\text { / Itsveridifəkəlt/ }\end{array}$ & $\begin{array}{l}\text { He's (is) angry } \\
\text { / hi:zængri/ } \\
\text { He's (has) been } \\
\text { angry } \\
\text { / hi:zbinæygri/ }\end{array}$ & $\begin{array}{l}\text { Riris's (is) sick } \\
\text { /ririsızsı/ } \\
\text { Anis's (has) } \\
\text { been away. } \\
\text { /anisızbınəwei/ }\end{array}$ \\
\hline
\end{tabular}




\section{Steps in using Jazz Chants}

1. First, the students are asked to identify the inflectional suffix $-s$ and/or-es in the Jazz Chants.

2. Next, they are asked to guess how each of them is pronounced.

3. Then, examples are given to the students of the pronunciations of $-s$ and/or -es (through teacher's model or video of Jazz Chant).After that, students are asked to pay attention to the teacher's pronunciations while checking whether their guesses are correct or not.

4. Sequentially, they are divided into two groups before playing the jazz chant. One group pronounces the lyrics with single asterisk, whereas the other group mentions the ones with double asterisks. After that, teacher can play a tape recorder of jazz chant; or teacher reads the jazz chant by himself/herself to introduce the students about the jazz chant's stress or intonation. In this activity, the students ought to give full attention to the whole jazz chant material, whether it is the pronunciations, stresses, or intonations. Then, students should repeat after the teacher, and jazz chant begins. While doing jazz chants, teacher can also combine the activity with some movements such as body gestures or some claps to build students' confidence and to make the class become more interesting. As a result, students will definitely understand the lesson faster because every student enjoys the class.

5. Afterwards, teacher explains that $-s$ and/or $-e s$ is pronounced in three (3) ways, i.e. as /s/; /z/; / Iz/ or /oz/ depending on the final sound of a word. (See the theory above)

6. Later, the students' understandings are checked by asking them to categorize the pronunciations of inflectional suffix $-s$ and/or $-e s$ in the words in the Jazz Chants into three groups.

\begin{tabular}{|c|c|c|}
\hline /s/ & /z/ & /ız/or /əz/ \\
\hline works /wə:ks/ & lives /lıvz/ & Anis's /anisız/ \\
\hline
\end{tabular}

7. Finally, the students' pronunciations are evaluated.

\section{Example of Jazz Chant's Lyric}

\section{The Banker's Wife Blues}

Where does John live?*

He lives near the bank.**

Where does he work?*

He works at the bank.** 
When does he work?*

He works all day and he works all night**

at the bank, at the bank at the great, big bank.**

Where does he study?*

He studies at the bank.**

Where does he sleep?*

He sleeps at the bank**

Why does he spend all day, all night, all day, all night, at the bank, at the bank?*

Because he loves his bank more than his wife**

And he loves his money more than his life.**

\section{CONCLUSION}

After having the practices of the pronunciations of suffix - sand/or $-e s$ using jazz chants, it was found out that about $75 \%$ of the students in each class consisting of 35 students could identify the differences in the pronunciations of suffix - sand/or $-e s$. They could categorize the words with final sounds - sand/or es into three different types of pronunciation. Besides, they could also pronounce them properly. This was shown by their performances in oral pronunciation test. However, when the pupils still made mistakes in pronouncing suffix - sand/or $-e s$, the teacher corrected them by asking the students to repeat after the teacher's corrections.

Based on the results of the pronunciation test, it is concluded that jazz chant tends to enhance students' English competences, not only their pronunciation, but also their vocabularies and grammatical patterns. Furthermore, it facilitates a large number of conveniences in practice due to its natural spoken English,its flexibility in class size and age group,no requirement of any special materials, and no need of musical ability.

\section{REFERENCES}

Azar, B. S., \& Hagen, S. A. (2009).Understanding And Using English Grammar (Fourth Edition ed.). New York, USA: Pearson Education.

Banker's Wife Blues - Jazz Chant.(n.d.). Retrieved October 1, 2016, from https://www.wattpad.com/8726176-banker's-wife-blues-jazz-chant

Crystal, D. (1997). A Dictionary of Linguistics and Phonetics. Oxford Ox4, UK: Blackwell Publishers Ltd.

Holiday Jazz Chants.(n.d.). Retrieved September 30, 2016, from elt.oup.com

Kelly, G., \& Harmer, J. (2000).How to TeachPronunciation. Charlbury, Oxfordshire, UK: Bluestone Press.

Kosur, H. M., \& Goss, T. (2012, January 17). Forming Plurals of Regular Nouns in English: Morphological, Spelling, and Pronunciation Changes. 
Retrieved October 2, 2016, from http://www.brighthubeducation.com/esllesson-plans/52818-spelling-and-pronunciation-rules-for-plural-nouns/

Richards, J. C., \& Rodgers, T. S. (1999). Approaches and Methods In Language Teaching. Cambridge CB2 2RU, UK: Cambridge University Press.

Teaching Jazz Chants to Young Learners. (n.d.). Retrieved October 1, 2016, from https://americanenglish.state.gov/resources/teaching-jazz-chants-younglearners 